\title{
PROSES PELESEPAN FONOLOGI PADA LEKSIKON BAHASA SUMBAWA DIALEK SUMBAWA BESAR
}

\author{
Umar \\ Program Doktor Linguistik Universitas Udayana \\ Umarstkip@gmail.com
}

\begin{abstract}
The users of Sumbawa's Besar dialect was used by many people in Sumbawa Regency. Almost Sumbawa region utilized Sumbawa's Besar dialect in getting communication. In a general way, this language is utilized word-of-mouth deep gab everyday among the users in the society member whereas in writing form is still found sparse. In this study used qualitative method. Meanwhile, the result of data analysis which is sound disappearance pprocess that happening in Sumbawa's Besar Dialect is Aferesis (sound disappearance on course startup), Sinkope (sound disappearance on course mean), and Apokope (sound disappearance on course final). This process happening on segment that do not accentual and in particular on homorgan's sounds. And there is factor even its happening causative sound disappearance are divided as two which are non-linguistics and linguistics factor.
\end{abstract}

Key word: Phonology disappearance, Sumbawa language, Sumbawa's Besar dialect

\section{A. PENDAHULUAN}

Sebagai mahkluk sosial, manusia tidak dapat berdiri sendiri. Dalam menjalani kehidupanya, ia selalu membutuhkan orang lain dan terikat dengan lingkungannya. Untuk itulah bahasa diperlukan sebagai media untuk mengkomunikaikan ide, gagasan, dan perasaannya kepada orang lain sehingga dapat terjalin hubungan sosial yang baik dan lancar.

Di Indonesia, selain Bahasa Indonesia yang merupakan bahasa nasional, juga terdapat beragam bahasa daerah, termasuk di dalamnya bahasa daerah yang terdapat di Nusa Tenggara Barat, khususnya Bahasa Sumbawa. Bahasa Sumbawa memiliki empat dialek yaitu Dialek Jereweh, Dialek Taliwang, Dialek Tongo, dan Dialek Sumbawa Besar (Mahsun, 1995:74).

Pemakai Dialek Sumbawa Besar (DSB) sangat banyak. Hampir sebagian wilayah Kabupaten Sumbawa menggunakan Bahasa Sumbawa Dialek Sumbawa Besar (BSDSB) dalam berkomunikasi. Pada umumnya, bahasa ini digunakan secara lisan dalam percakapan sehari-hari di kalangan anggota masyarakat penuturnya sedangkan dalam bentuk tulisan masih jarang ditemukan.

Di dalam prakteknya, ada kecenderungan para penutur BSDSB dan juga penutur bahasa lainnya, berusaha untuk "menghemat" tenaga dalam pemakaian bahasa dengan cara memperpendek tuturan-tuturannya, sejauh hal itu tidak bertentangan dengan budaya tempat bahasa tersebut digunakan. Dalam bahasa, sifat hemat ini lazim disebut "ekonomi bahasa" (Verhaar, 1996:85-86).

Perpendekan tuturan tersebut mengikuti hukum-hukum yang bermacam-macam. Salah satunya adalah kaidah fonologis yaitu berupa perpendekan pada segmen-segmen yang tidak bertekanan. Penghilangan seperti itu dinamakan "penghilangan fonem" (satu atau lebih) dan ada pula yang berupa kontraksi. Namun pada penelitian ini, peneliti hanya membahas tentang penghilangan fonem saja, yang selanjutnya digunakan istilah pelesapan bunyi, bukan fonem, karena tidak membedakan makna.

Menurut Mahsun (2007:26), ada beberapa 
jenis pelesapan bunyi yang telah dikenal, yaitu aferesis (pelesapan bunyi pada poisi awal), sinkope (penghilangan bunyi pada poisi tengah). Dan apokope (penghilangan bunyi pada posisi akhir).

Ada banyak hal yang menyebabkan terjadinya pelesapan bunyi. Selain karena keinginan untuk menghemat tenaga dan mempermudah tuturan, menurut Verhaar (1993:47) hal ini juga disebabkan oleh dalam parole suatu bahasa, penutur cenderung lalai dalam artikulasi yang sulit. Mengenai faktorfaktor yang menyebabkan terjadinya pelesapan bunyi ini akan dibahas pada bagian tersendiri.

Pelesapan bunyi memang cukup sering dilakukan oleh para penutur bahasa, khususnya penutur BSDSB dalam komunikasi sehari-hari. Namun tidak banyak yang mengetahui peristiwa itu karena dianggap sebagai suatu hal yang biasa dan telah terjadi secara turun-temurun. Hal inilah yang mendorong peneliti untuk mengangkat masalah ini sebagai objek penelitian sehingga para pembaca dapat mengetahui bentuk-bentuk peristiwa yang telah akrab dalam tuturan sehari-hari itu secara jelas. Selain itu, menurut pengetahuan peneliti, masalah ini belum pernah diangkat sebagai objek penelitian.

\section{B. RUMUSAN MASALAH}

Berdasarkan uraian latar belakang di atas, masalah yang diangkat dalam penelitian ini adalah sebagai berikut.

1. Bagaimanakah bentuk-bentuk pelesapan bunyi yang terdapat di dalam BSDSB?

2. Faktor-faktor apakah yang menyebabkan terjadinya pelesapan bunyi di dalam BSDSB?

\section{TUJUAN PENELITIAN}

Berdasarkan uraian rumusan masalah di atas, tujuan yang diangkat dalam penelitian ini adalah sebagai berikut.

1. Untuk mendeskripsikan bentuk-bentuk pelesapan bunyi yang terdapat di dalam BSDSB.

2. Untuk mendeskripsikan faktor-faktor apa saja yang menyebabkan terjadinya pelesapan bunyi di dalam BSDSB.

\section{KAJIAN PUSTAKA}

Dalam sejarah perkembangan suatu bahasa, nilai fonetik suatu segmen dapat berubah melalui banyak cara. Ada yang terjadi melalui pelesapan bunyi dan ada juga yang disebabkan oleh proses penyisipan/penambahan bunyi (lihat Mahsun, 2007:26). Dalam makalah ini peneliti hanya membahas tentang penghilangan bunyi, yaitu berupa aferesis, sinkope, dan apokope.

Aferesis merupakan suatu gejala bahasa berupa penghilangan bunyi awal tanpa mengubah makna kata itu. Aferesis berasal dari Bahasa Latin, Afere, yang berarti 'mengambil' (Notosudirjo, 1991:7). Sebagai contoh, dalam Bahasa Indonesia wujud > ujud. Namun Kridalaksana (2001:2) menyatakan bahwa aferesis merupakan penanggalan bunyi atau kata dari awal sebuah ujaran, misalnya: Selamat pagi! > Pagi! Jadi penghilangan bunyi di sini tidak terbatas pada penghilangan satu atau dua bunyi saja, melainkan dapat juga berupa kata. Namun peneliti merujuk pada teori yang menyatakan bahwa aferesis merupakan penghilangan bunyi awal (satu atau lebih), karena dari data yang didapatkan di lapangan, peneliti hanya menemukan hal tersebut sedangkan penghilangan kata awal belum ditemukan.

Sinkope berasal dari Bahasa Latin, Sinus, yang berarti 'kerut atau lekuk'. Sinkope merupakan suatu gejala bahasa berupa penghilangan bunyi pada posisi tengah tanpa mengubah arti kata itu. Misalnya; sahaya $>$ saya (Notosudirjo, 1991:64, Mahsun, 2007:26, Kridalaksana, 2001:198).

Apokope merupakan suatu gejala bahasa berupa penghilangan bunyi pada posisi akhir tanpa mengubah arti kata itu. Apokope berasal dari Bahasa Latin, Apoculo, 'hilang' (dalam Bahasa Inggris Apocope). Misalnya, pelangit $>$ pelangi. Dalam Bahasa Betawi juga ditemukan kata berabeh $>$ berabe.

Contoh-contoh penghilangan bunyi dalam Bahasa Sumbawa khususnya BSDSB akan dipaparkan pada bagian pembahasan. 


\section{E. METODE PENELITIAN}

\section{Populasi dan Sampel}

Populasi merupakan keseluruhan subjek penelitian (Arikunto, 2002:108). Dalam penelitian linguistik, populasi pada umumnya adalah keseluruhan individu dari segi bahasa tertentu (Subroto dalam Nurhasanah, 2004:16). Oleh karena itu, sesuai dengan objek yang diteliti, maka populasinya adalah Bahasa Sumbawa yang dipakai oleh penutur DBS.

Sedangkan sampel adalah bagian dari populasi yang dijadikan objek penelitian. Menurut Arikunto (2004:109), sampel adalah sebagian atau wakil populasi yang diteliti. Karena banyaknya jumlah populasi dan tidak mungkin untuk diteliti seluruhnya, maka peneliti melakukan pemilihan sampel dengan data yang bersumber dari informan yang diambil dari penutur asli Bahasa Sumbawa sebanyak lima orang. Semua informan dipilih dan ditetapkan berdasarkan syarat pemilihan informan yaitu;(1) penutur asli Bahasa Sumbawa yang sehat jasmani dan rohani,(2) menguasai bahasanya secara mantap dalam pengertian bahwa mereka menguasai struktur bahasanya dengan baik, (3) memiliki kosa kata yang lengkap, (4) dapat mengucapkan bunyi dengan sempurna, (5) mengetahui latar belakang budaya bahasanya, dan (6) berpendidikan minimal SD (Nurhasanah, 2004:17).

\section{Metode Pengumpulan Data}

1) Metode Cakap

Metode cakap dinamakan juga metode percakapan. Penamaan metode cakap berkaitan dengan cara yang ditempuh dalam pengumpulan data, yaitu berupa percakapan antara peneliti dengan informan (Mahsun, 2007:95). Untuk memperoleh data yang dibutuhkan, peneliti menggunakan teknik pancingan dan catat dengan tujuan untuk memunculkan data kebahasaan berupa penghilangan bunyi dalam BSDSB.

2) Metode Simak

Menurut Mahsun (2007:92), metode simak merupakan metode yang digunakan dalam pengumpulan data dengan cara menyimak penggunaan bahasa. Peneliti mengunakan metode ini untuk mendapatkan data berupa penghilangan bunyi dalam BSDSB yang dipakai oleh penuturnya, yaitu dengan cara menyadap hasil pembicaraan antara informan dengan peneliti atau dengan orang lain (sesama penutur BSDSB). Selain itu, peneliti juga menggunakan teknik catat untuk mendata bentuk-bentuk yanng disadap. Selanjutnya, teknik lanjutan yang dilakukan adalah teknik simak libat cakap karena peneliti melakukan penyadapan dengan cara berpartisipasi sambil menyimak.Selain itu, peneliti juga melakukan penyimakan terhadap teks lawas yang dikutip dari lawas cerita Tanjung Menangis, Buen Lajenre, dll. untuk membantu menjelaskan perubahan-perubahan yang dialami oleh suatu kata. Peneliti juga memberlakukan diri sebagai penyedia data. Hal ini didasarkan pada pendapat bahwa peneliti sebaiknya penutur asli dan peneliti yang baik adalah peneliti yang meneliti bahasa yang dikuasainya (Nurhasanah, 2004:18).

\section{Metode Analisis Data}

Metode analisis data yang digunakan di dalam penelitian ini adalah metode rekonstruksi prabahasa. Dalam hal ini metode yang digunakan adalah metode padan intralingual (PI) dengan teknik dasar berupa teknik hubung banding intralingual (THBI) untuk merekonstruksi bentukbentuk prabahasanya.

\section{Metode Penyajian Hasil Analisis Data}

Hasil data yang dianalisis disajikan dengan menggunakan metode informal dan metode formal (Mahsun, 2007:123). Maksud dari metode informal adalah menyajikan analisis data dengan menggunakan kata-kata atau kaliamat bukan dengan lambang-lambang. Sedangkan metode formal yaitu dengan menggunakan tanda-tanda atau lambang-lambang.Dalam penyajian hasil analisis data ini, peneliti menggunakan singkatan nama dan beberapa tanda atau lambang yaitu :BSDSB, dSB, tanda petik satu '...' dan lambang ... >... 


\section{F. PEMBAHASAN}

Bentuk-Bentuk Peghilangan Bunyi yang Terdapat Di Dalam Bahasa Sumbawa Dialek Sumbawa Besar (BSDSB). Bentuk-bentuk penghilangan bunyi dalam BSDSB adalah sebagai berikut.

1. Aferesis (penghilangan bunyi pada posisi awal)
a. ade > de 'yang'
b. ntEk > tEk 'naik'
c. garu $>$ aru 'ganggu'
d. kakuda > kuda 'mengapa'
e. lako > ko 'ke mana'
f. lema > ema 'cepat'
g. mlalo > malo 'masa sih'
h. mnan > nan 'begitu'
i. muntu $>$ ntu 'sedang'
j. ninta $>$ nta 'di sini'
k. ngano > ano 'hari'
1. nonda $>$ nda 'tidak ada'
m. papin > pin 'nenek/kakek'
n. sajan > ajan 'makin/seandainya'
o. saperap > perap 'kemarin'
p. sijar > ijar 'dasar'
q. siyong > iyong 'bukan'
r. tita > ita 'tadi'
s. waya > aya 'waktu'

Pada contoh-contoh di atas proses penghilangan bunyi pada posisi awal terjadi karena adanya segmen-segmen yang tidak bertekanan sehingga para penutur melakukan pelesapan.

2. Sinkope (penghilangan bunyi pada posisi tengah )
a. andi > adi 'adik/adinda'
b. bnrang > brang 'sungai'
c. bnru > bru 'baru'
d. gnras > gras 'sangat'
e. jnring > jring 'tepi/pinggir'
f. kmbo > kbo 'kerbau'
g. lampa > ampa 'ternyata'
h. pndi > pdi 'kasihan'
i. rmban > rban 'bendungan'
j. rmbin $>$ rbin 'embun'
k. snda > sda 'suara'
l. sndi > sdi 'sedikit'

$$
\begin{aligned}
& \text { m. sungki > suki 'kunci' } \\
& \text { n. tnri > tri 'jatuh' }
\end{aligned}
$$

Pada contoh-contoh di atas, terdapat pembentukan pola seperti $\mathrm{n}$ bertemu dengan $\mathrm{r}$, $\mathrm{n}$ bertemu dengan $\mathrm{d}, \mathrm{m}$ bertemu dengan $\mathrm{p}$, dan $m$ bertemu dengan $p$ cenderung mengalami penghilangan. Hal ini disebabkan oleh bunyibunyi tersebut merupakan bunyi-bunyi homorgan, yaitu bunyi yang diartikulasikan pada tempat yang sama, misalnya $\mathrm{m}$ dan $\mathrm{b}$ atau dengan $\mathrm{p}$ sama-sama merupakan bunyi bilabial yang dihasilkan dengan penyempitan kedua bibir sehingga artikulasinya mudah terabaikan karena dihasilknan dengan cara yang sama.

Selainitu, adakata-katatertentuyangmengalami dua kali proses penghilangan bunyi yaitu:adi (yandi $>$ andi $>$ adi), pdi (pamndi $>$ pndi $>$ pdi), dan sdi (sakndi >sndi> sdi). Hal ini disebabkan oleh perubahan tersebut terjadi secara bertahap dari bentuk yang paling purba hingga ke bentuk yang lazim dipakai saat ini/modern.

3. Apokope (penghilangan bunyi pada posisi akhir)
a. ba tu > bat 'akan kita/ayo kita'
b. ka mo > kam 'sudah'
c. ka si > kas 'sudah'
d. ma tu > mat 'mari kita'
e. me mo > mem 'mana'
f. no mo > nom 'tidak usah'
g. no si > nos 'tidak'
h. ya ku > yak 'akan aku'
i. ya mu > yam 'akan kamu'
j. ya tu > yat 'akan kita'

Pada contoh-contoh di atas, kata tu, mo, si, dan ku mengalami proses penghilangan pada posisi akhir, karena kata-kata tersebut merupakan segmen-segmen yang tidak bertekanan sehingga untuk mempermudah tuturan, penutur melakukan penghematan dengan melesapkan bunyi pada posisi akhir sehingga terjadilah peristiwa apokope.

Faktor-Faktor yang Menyebabkan Terjadinya Penghilangan Bunyi Di Dalam Bahasa Sumbawa Dialek Sumbawa Besar (BSDSB)

Ada beberapa faktor yang menyebabkan terjadinya penghilangan bunyi di dal dalam BSDSB, 
di antaranya:

\section{Faktor Linguistik}

Penghilangan bunyi terjadi karena pengaruh parole. Dalam parole (ujaran) suatu bahasa, penutur bahasa cenderung lalai dalam artikulasi yang terlalu sulit. Misalnya pada bunyi nasal $\mathrm{m}$ atau $\mathrm{n}$ yang merupakan bunyi hentian bersuara yang dinasalisasikan. Ketika orang melafalkan kata r mban, uvula naik menutupi rongga hidung pada saat berpindah dari $\mathrm{m}$ ke $\mathrm{b}$. Konsonan $\mathrm{m}$ dan b sama-sama merupakan konsonan bilabial yang dihasilkan dengan penyempitan kedua bibir sehingga menuntut adanya kegiatan artikulatoris yang mudah terlalaikan sebab dihasilkan pada tempat yang sama, sehingga kata yang bersangkutan dengan bunyi yang dilangkahi itu mulai biasa terpakai.

\section{Faktor Nonlinguistik}

Seiring dengan berkembangnya peradaban manusia, bahasa sebagai media untuk berkomunikasi dengan sesamanya pikut berubah. Pergerakan kehidupan yang semakin cepat dan sibuk membuat para penutur berusaha untuk menghemat tuturannya dengan melakukan perpendekan tuturan, salah satunya dengan penghilangan bunyi, selama itu menjadi kesepakatan dan tidak menghambat proses komuikasi.

\section{G. KESIMPULAN}

1. Proses penghilangan bunyi yang terjadi di dalam BSDSB adalah aferesis (penghilangan bunyi pada posisi awal), sinkope (penghilangan bunyi pada posisi tengah), dan apokope (penghilangan bunyi pada posisi akhir). Proses ini terjadi pada segmen-segmen yang tidak bertekanan dan khususnya pada bunyi-bunyi homorgan.
2. Faktor-faktor yang menyebabkan terjadinya penghilangan bunyi dibagi menjadi dua yaitu, faktor linguistik dan faktor nonlinguistik. Faktor linguistik yaitu adanya kelalaian para penutur bahasa dalam parole terutama pada artikulasi yang terlalu sulit. sedangkan faktor nonlinguistik yaitu adanya kecenderungan para penutur bahasa untuk menghemat tenaga dalam bertutur dan untuk mempermudah tuturannya.

\section{H. DAFTAR PUSTAKA}

AR, Syafruddin.1999. Pelajaran Bahasa Daerah Basa Samawa. Sumbawa

Arikunto, Suharsimi. 2002. Prosedur Penelitian:Suatu Pendekatan Praktek. Jakarta:Rineka Cipta.

Kridalaksan, Harimurti. 2001. Kamus Linguistik. Jakarta:Gramedia Pustaka Utama.

Mahsun. 1995. Dialektologi Diakronis:Sebuah Pengantar. Yogyakarta:Gadjah Mada University Press.

--------. 2007. Linguistik Historis Komparatif. Yogyakarta:Gama Media. Metode Penelitian Bahasa;Tahapan

Strategi, Metode, dan Tekniknya. Jakarta:Raja Grafindo Persada.

Notosudirjo, Suwardi. 1991. Kosakata Istilah Linguistika untuk SMTA. Yogyakarta:Kanisius. Nurhasanah. 2004. "Kalimat Negatif Dalam Bahasa Sumbawa Dialek Sumbawa Basar."Mataram:Universitas Mataram.

Saussure, de Ferdinand. 1993. Pengantar Linguistik Umum. Yogyakarta:Gadjah Mada University Press.

Verhaar, JWM. 1993. Pengantar Linguistik. Yogyakarta:Gadjah Mada Universuty Press. 1996. Asas-Asas Linguistik Umum.

Yogyakarta:Gadjah Mada University Press 